\title{
Antibacterial and antiproliferative peptides in synbiotic yogurt- Release and stability during refrigerated storage
}

\author{
B. N. P. Sah, ${ }^{*}$ T. Vasiljevic, ${ }^{*}$ S. McKechnie, $†$ and O. N. Donkor ${ }^{* 1}$ \\ *Advanced Food Systems Research Unit, College of Health and Biomedicine, and \\ †Advanced Food Systems Research Unit, College of Engineering and Science, Victoria University, Werribee Campus, PO Box 14428, Melbourne, \\ Victoria 8001, Australia
}

\section{ABSTRACT}

The search for alternative therapeutics is on the rise due to the extensive increase in bacterial resistance to various conventional antibiotics and side effects of conventional cancer therapies. Bioactive peptides released from natural sources such as dairy foods by lactic acid bacteria have received attention as a potential source of biotherapeutic peptides. However, liberation of peptides in yogurt depends on proteolytic activities of the cultures used. Thus, this research was conducted to establish generation of inhibitory peptides in yogurt against pathogenic bacteria and cancer cells during storage at $4^{\circ} \mathrm{C}$ for $28 \mathrm{~d}$. Water-soluble crude peptide extracts were prepared by high-speed centrifugation of plain and probiotic yogurts supplemented with or without pineapple peel powder (PPP). The inhibition zones against Escherichia coli and Staphylococcus aureus by PPP-fortified probiotic yogurt at $28 \mathrm{~d}$ of storage were, respectively, 25.89 and $11.72 \mathrm{~mm}$ in diameter, significantly higher than that of nonsupplemented control yogurts. Antiproliferative activity against HT29 colon cancer cells was also significantly higher in probiotic yogurt with PPP than in nonsupplemented probiotic yogurt. Overall, crude water-soluble peptide extracts of the probiotic yogurt with PPP possessed stronger inhibitory activities against bacteria and cancer cells than controls, and these activities were maintained during storage. However, activities were lowered substantially during in vitro gastrointestinal digestion. These findings support the possibility of utilizing dairy-derived bioactive peptides in the development of a superior alternative to the current generation of antibacterial and anticancer agents, as well as a functional ingredient in foods, nutraceuticals, and pharmaceuticals.

Key words: pineapple, probiotics, peptides, antibacterial activity, anticancer activity

\footnotetext{
Received October 8, 2015.

Accepted February 11, 2016.

${ }^{1}$ Corresponding author: Osaana.Donkor@vu.edu.au
}

\section{INTRODUCTION}

Rapid industrialization and urbanization has resulted in immense changes to lifestyle practices, leading to increased risks of various diseases and disorders, such as cancer. Cancer, an uncontrolled growth and spreading of abnormal cells, has become a major health burden in the United States and many other parts of the world (Siegel et al., 2012). Colorectal cancer is a widespread cancer, the fourth most common in men and third in women in Latin America (Goss et al., 2013). Side effects such as alopecia (hair loss), fatigue, nausea, and vomiting are associated with conventional cancer therapies, such as chemotherapy and radiotherapy, because they adversely affect healthy cells as they destroy malignant cells. In addition, there is increasing resistance against conventional chemotherapy. Consequently, there is an urgent demand for natural anticancer compounds, including bioactive peptides, as an alternative treatment to chemotherapy drugs, which could eliminate some drawbacks of chemotherapy.

Some bioactive peptides exhibit interesting cytotoxic activities against both malignant and microbial cells (Hoskin and Ramamoorthy, 2008). Positively charged antimicrobial peptides (AMP) can bind with negatively charged components of bacterial and cancer cells electrostatically, which may play a critical role for the disruption of bacterial and cancer cell membranes (Yeaman and Yount, 2003; Hoskin and Ramamoorthy, 2008). Most AMP are relatively small (6 to $100 \mathrm{AA}$ ), cationic, amphipathic, and $\alpha$-helical peptides and demonstrate broad-spectrum antibacterial and antifungal activities, usually by lysing cell membranes (Giuliani et al., 2007; Yeung et al., 2011). The widespread increase in bacterial resistance to several common antibiotics has inspired scientists to focus on exploring new groups of antibiotics with new target sites and action modes.

Consequently, interest is growing in food-derived peptides as drug candidates, mainly due to several specific key merits over common chemotherapeutics. Notably, milk proteins emerge as a prolific source of biologically active peptides, which are encrypted in the 
primary structure of the proteins and could modulate the physiology of consumers following the proteolytic release of peptides with anticarcinogenic potential (Bhat and Bhat, 2011; Sah et al., 2015a). One way to obtain these bioactive peptides is by direct release from proteins by proteolytic actions of bacteria commonly used in manufacturing fermented foods (Choi et al., 2012). Therefore, yogurt appears to be an appropriate matrix for production of such functional ingredients.

Several investigations have been conducted to increase the functionality of yogurt such as probiotic inclusion in culture and prebiotic supplementation (Donkor et al., 2007a; Al-Sheraji et al., 2012; Sah et al., 2015b, 2016). A prebiotic is "a selectively fermented ingredient that allows specific changes, both in the composition and/or activity in the gastrointestinal microflora that confers benefits upon host well-being and health" (Gibson et al., 2004). Common prebiotics are inulin, fructooligosaccharides, galactooligosaccharides, and other oligosaccharides, such as resistant starch and lactulose (Thammarutwasik et al., 2009). Inulin represents a group of plant polysaccharides having linear fructans with $\beta-(2 \leftarrow 1)$ fructosyl-fructose glycosidic linkages, and "inulin HP" is a long-chain inulin with a degree of polymerization of 10 to 60 , the average being 25 (Roberfroid, 2007). Besides inulin, pineapple peel powder (PPP) appears to be a good source of dietary fiber, protein, and minerals, with apparent prebiotic potential (Sah et al., 2015c).

Although prebiotic supplementations may result in several functional benefits for probiotic organisms and ultimately consumers, the approach may influence the bioactivity of yogurt because bacterial proteolytic enzymes further hydrolyze milk proteins and peptides during storage (Donkor et al., 2007b). However, studies are still largely limited regarding the effects of prebiotic addition on inhibitory activities against bacteria and HT29 human colon cancer cells of the released peptides in yogurt during storage. This work thus aimed to assess the effect of PPP addition on performance of $\mathrm{Lac}$ tobacillus acidophilus (ATCC 4356), Lactobacillus casei (ATCC 393), and Lactobacillus paracasei ssp. paracasei (ATCC BAA52) in regard to the liberation of bioactive peptides with antibacterial and anticancer potential in yogurts during $28 \mathrm{~d}$ of refrigerated storage at $4^{\circ} \mathrm{C}$.

\section{MATERIALS AND METHODS}

\section{Substrates and Chemicals}

McCoy's 5A (Modified) medium and trypsinEDTA $(0.25 \%)$ were procured from Life Technologies (Carlsbad, CA). Bovogen Biologicals Pty Ltd. (Mel- bourne, Australia) supplied fetal bovine serum (FBS). CellTiter $96 \quad \mathrm{AQ}_{\text {ueous }}$ One Solution reagent containing a tetrazolium compound [3-(4,5-dimethylthiazol-2-yl)5-(3-carboxymethoxyphenyl)-2-(4-sulfophenyl)-2Htetrazolium, inner salt; MTS] and an electron-coupling reagent (phenazine ethosulfate) was purchased from Promega Corp. (Madison, WI) for the cell proliferation assay. Antibiotic/antimycotic solution $(100 \times)$ and staurosporine solution (from Streptomyces sp.) were obtained from Sigma Chemical Co. (St. Louis, MO). Pepsin (cat. no. P7000; pepsin A; EC 3.4.23.1, 570 U/ $\mathrm{mg}$ solid, from porcine gastric mucosa), pancreatin [cat. no. 1494057; pancreatin, amylase, and protease United States Pharmacopeia reference standard; each mg contains 344 USP units of amylase activity and 358 USP units of protease activity], and bile (catalog number B3883; bile bovine) were also purchased from Sigma Chemical Co. Cellstar T25 and T75 flasks, 96well flat-bottomed microplate (Cellstar, Greiner BioOne GmbH, Frickenhausen, Germany) were obtained from Interpath Services Pty. Ltd. (Heidelberg West, VIC, Australia). Ampicillin sodium salt was purchased from Progen Industries Ltd. (Darra, QLD, Australia). Thermo Fisher Scientific Australia Pty Ltd. (Scoresby, VIC, Australia) supplied nutrient agar no. 1 (CM0003; Oxoid, Basingstoke, UK). Aqueous solutions were prepared in Milli-Q water $(18.2 \mathrm{M} \Omega \cdot \mathrm{cm})$ obtained from a Millipore water purification system (Millipore Australia Pty Ltd., North Ryde, NSW, Australia). Skim milk powder and whole pineapples were bought from a local supermarket (Woolworths Limited, Werribee, Australia). Pineapple peel powder was prepared from the peel of pineapple (Ananas comosus [L.] Merrill) as described by Sah et al. (2015b).

\section{Propagation of Cultures and Preparation of Yogurts Supplemented with Prebiotics}

Pure cultures of Streptococcus thermophilus ASCC 1275 and Lactobacillus delbrueckii ssp. bulgaricus Lb1466 (L. bulgaricus) were obtained from the Victoria University Culture Collection (Werribee, Australia). Lactobacillus acidophilus ATCC 4356, L. casei ATCC 393, and L. paracasei ssp. paracasei ATCC BAA52 ( $L$. paracasei) were procured from Cell Biosciences Pty Ltd. (Heidelberg, VIC, Australia). All organisms were stored at $-80^{\circ} \mathrm{C}$ in de Man, Rogosa, and Sharpe broth containing $40 \%$ (vol/vol) glycerol. The strains resuscitated after 3 successive transfers were used to prepare starters as described by Sah et al. (2014).

Set-type plain and probiotic yogurts with inulin or PPP supplementation or without supplementation (control) were prepared as described by Sah et al. 
Table 1. Experimental design to evaluate production and stability of antibacterial and antiproliferative peptides in yogurt during refrigerated storage $^{1}$

\begin{tabular}{ll}
\hline Prebiotic $(1 \%$ wt/vol $)$ & Combination of cultures $(1 \%$ vol/vol each) \\
\hline None $($ Control 1$)$ & Streptococcus thermophilus + Lactobacillus bulgaricus \\
None (Control 2$)$ & S. thermophilus + L. bulgaricus + Lactobacillus acidophilus + Lactobacillus casei + Lactobacillus paracasei \\
Inulin (Orafti HP $\left.\mathrm{HP}^{2}\right)$ & S. thermophilus + L. bulgaricus + L. acidophilus + L. casei + Laracasei \\
Pineapple peel powder & S. thermophilus + L. bulgaricus + L. acidophilus + L. casei + Laracasei \\
\hline
\end{tabular}

${ }^{1}$ Yogurt culture $=S$. thermophilus + L. bulgaricus; probiotic cultures $=$ L. acidophilus + L. casei + L. paracasei.

${ }^{2}$ Beneo-Orafti Ltd. (Tienen, Belgium).

(2014). Briefly, 4 batches of milk base were prepared by reconstituting skim milk powder in Milli-Q water at $140 \mathrm{~g} / \mathrm{L} ; 2$ batches were separately supplemented with $1.0 \%$ (wt/vol) of commercial inulin Orafti HP (BeneoOrafti Ltd., Tienen, Belgium) or PPP. All milk bases were heated for $30 \mathrm{~min}$ at $85^{\circ} \mathrm{C}$, cooled to $45^{\circ} \mathrm{C}$, and then inoculated with $1.0 \%$ (vol/vol) of $S$. thermophilus and L. bulgaricus monocultures aseptically. Three mixes (2 supplemented mixes, and 1 nonsupplemented control) were further inoculated with $1 \%$ (vol/vol) of each probiotic monoculture (Table 1). The final mixes were aliquoted into polystyrene cups, and incubated at $42^{\circ} \mathrm{C}$ until pH of $4.5 \pm 0.05$ was achieved. Thereafter, the yogurts were immediately cooled to $4^{\circ} \mathrm{C}$ and stored for $28 \mathrm{~d}$.

\section{Preparation of Water-Soluble Peptide Extracts}

Water-soluble peptide extracts (WSPE) were prepared by high-speed centrifugation of yogurt samples as described by Sah et al. (2014). Briefly, samples were centrifuged at 22,680 $\times g$ using a JLA-16.250 rotor in an Avanti J-26S XPI High-Performance Centrifuge (Beckman Coulter Inc., Brea, CA) at $4^{\circ} \mathrm{C}$ for $30 \mathrm{~min}$. The supernatant was collected and freeze-dried using an Alpha 1-4 LSC Christ freeze dryer (Martin Christ Gefriertrocknungsanlagen GmbH, Osterode, Germany) and stored at $-80^{\circ} \mathrm{C}$ until further analysis. The protein content $(\mathrm{mg} / \mathrm{mL})$ of the WSPE was estimated according to Bradford (1976) using BSA (0.1-1.4 mg/mL) as standard.

\section{Determination of Antibacterial Activity}

An agar well diffusion assay was performed to assess inhibitory activity of WSPE against target strains [gram-negative: Escherichia coli (ATCC CRM-8739) and gram-positive: Staphylococcus aureus ssp. aureus (ATCC 25923)] as described by Vieira et al. (2014) with some modifications. Briefly, $100 \mu \mathrm{L}$ of a serially diluted overnight culture of the test organism (1 to 5 $\times 10^{5}$ cells $/ \mathrm{mL}$ ) was spread on nutrient agar plates.
Wells (6 $\mathrm{mm}$ in diameter) were made in agar using a sterilized stainless steel borer. Each well was filled with $100 \mu \mathrm{L}$ of sterilized WSPE in PBS $(\mathrm{NaCl}=8.475 \mathrm{~g} / \mathrm{L}$, $\mathrm{Na}_{2} \mathrm{HPO}_{4}=1.093 \mathrm{~g} / \mathrm{L}$, and $\mathrm{NaH}_{2} \mathrm{PO}_{4}=0.276 \mathrm{~g} / \mathrm{L}$; $\mathrm{pH} 7.4 ; 500 \mu \mathrm{g}$ of protein $/ \mathrm{mL})$. The plates were left at $4^{\circ} \mathrm{C}$ for $4 \mathrm{~h}$ to allow peptide diffusion in the medium, and then incubated aerobically at $37^{\circ} \mathrm{C}$ for 16 to $18 \mathrm{~h}$. Subsequently, the diameter of inhibition zones in $\mathrm{mm}$ (including the well) was measured. Ampicillin $(500 \mu \mathrm{g} /$ $\mathrm{mL}$ ) was used as a positive control and PBS was used as a negative control.

The morphological changes induced by the WSPE on E. coli ATCC 8739 and $S$. aureus ATCC 25923 were studied using scanning electron microscopy as described by Zhao et al. (2015) with some modifications. Briefly, $300 \mu \mathrm{L}$ of suspension of log-phase tested bacteria in $\mathrm{Nu}-$ trient broth No. 1 (optical density at $600 \mathrm{~nm}$ of $\sim 0.1$ ) was treated with $600 \mu \mathrm{L}$ of sterilized WSPE sample (at $500 \mu \mathrm{g}$ of protein $/ \mathrm{mL}$ in PBS) in a sterile 1.5-mL Eppendorf tube and incubated for $6 \mathrm{~h}$ at $37^{\circ} \mathrm{C}$. The WSPE was prepared from probiotic yogurt with PPP stored at $4^{\circ} \mathrm{C}$ for $28 \mathrm{~d}$. After incubation, cells were washed twice with sterile PBS, pelleted $(16,000 \times g, 2 \mathrm{~min})$. Then, $200 \mu \mathrm{L}$ of fixative $(2.5 \%$ glutaraldehyde solution in PBS) was slowly added and gently mixed. After $10 \mathrm{~min}$, the cells were pelleted; the spent fixative was replaced with the fresh, and further fixing was allowed overnight at $4^{\circ} \mathrm{C}$. The pellet was washed thrice with sterile Milli-Q water, dehydrated rapidly with ascending concentrations of aqueous ethanol series $(25,50,75$, and $90 \%$, and 3 times with $100 \%$ for 10 min each), and dried further using 1,1,1,3,3,3-hexamethyldisilazane (HMDS) at 1:2 HMDS:ethanol, 2:1 HMDS:ethanol, and $100 \%$ HMDS for $10 \mathrm{~min}$ each. Finally, the cell pellet was directly mounted on an aluminum scanning electron microscopy stubs, air-dried overnight at room temperature in a biosafety cabinet, and sputtered with gold $(\sim 18 \mathrm{~nm})$ using a Jeol NeoCoater (model MP19020 NCTR). Fields of the specimen were examined under a high-vacuum NeoScope JCM-5000 benchtop SEM (Jeol Ltd., Tokyo, Japan) and micrographs were recorded. 


\section{Cell Culture and Assessment of Antiproliferative Activity Against HT-29 Cells}

A human colorectal cancer cell line, HT29 (ATCC HTB38), was obtained from the American Type Culture Collection (Manassas, VA). The HT-29 cells were maintained in McCoy's 5A (Modified) complete growth medium containing 10\% FBS and $1 \%$ antibioticantimycotic solution and incubated at $37^{\circ} \mathrm{C}$ in a $\mathrm{CO}_{2}$ incubator (Shanghai Lishen Scientific Equipment Co. Ltd., Shanghai, China) in a humidified air atmosphere containing $5 \% \mathrm{CO}_{2}$. The cells grew as monolayers in 75$\mathrm{cm}^{2}$ tissue culture flasks, where the cell culture medium was changed every 48 to $72 \mathrm{~h}$ and cells passaged at 80 to $90 \%$ confluency using $0.25 \%$ trypsin-EDTA $(1 \times)$ to detach cell lines. Viable cells were counted according to the trypan blue dye exclusion method using a hemocytometer.

The antiproliferative effect of WSPE on HT29 cells was assessed through MTS assay as described by Yan et al. (2013) with some modifications. Briefly, $100 \mu \mathrm{L}$ of a logarithmically growing cell suspension in the McCoy's 5 A complete growth medium $\left(\sim 2.0 \times 10^{4}\right.$ cells $/$ $\mathrm{mL}$ ) was dispensed in a well of a 96-well flat-bottomed plate, and the plate was preincubated at $37^{\circ} \mathrm{C}$ for $24 \mathrm{~h}$ in a $\mathrm{CO}_{2}$ incubator to allow cells to adhere. The medium was replaced with $100 \mu \mathrm{L}$ of fresh McCoy's 5A complete medium containing WSPE at a protein concentration of $250 \mu \mathrm{g} / \mathrm{mL}$ prepared by dissolving WSPE in complete growth medium, adjusting $\mathrm{pH}$ to $7.3 \pm$ 0.1 , and filter-sterilized using a sterile cellulose acetate syringe filter $(0.20 \mu \mathrm{m}$; Advantec MFS Inc., Dublin, $\mathrm{CA}$ ). The microplate was further incubated at $37^{\circ} \mathrm{C}$ for $24 \mathrm{~h}$ in the $\mathrm{CO}_{2}$ incubator. Then, $20 \mu \mathrm{L}$ of CellTiter 96 $\mathrm{AQ}_{\text {ueous }}$ One Solution reagent was added to each well, incubated at $37^{\circ} \mathrm{C}$ for $4 \mathrm{~h}$ in the $\mathrm{CO}_{2}$ incubator, and subjected to absorbance measurement at $490 \mathrm{~nm}$ using an iMark Microplate Absorbance Reader (Bio-Rad Laboratories, Hercules, CA). The plate included blank wells containing the same volume of complete McCoy's $5 \mathrm{~A}$ medium instead of WSPE sample. Staurosporine $(500 \mathrm{ng} / \mathrm{mL}$ ) was used as a positive control in the assay. Antiproliferative activity of the WSPE was calculated as follows:

$$
\text { Antiproliferative acitivity }(\%)=\left[\frac{A_{b}-A_{s}}{A_{b}-A_{c}}\right] \times 100,
$$

where $A_{s}$ is the absorbance of sample; $A_{b}$ is the absorbance of blank, using the same volume of culture medium instead of the sample; and $A_{c}$ is the absorbance of the control, using the same volume of culture medium without cells and samples.

\section{In Vitro Gastrointestinal Digestion}

In vitro gastrointestinal (GI) digestion of WSPE was performed as described by Minekus et al. (2014) with some modifications. Briefly, $10 \mathrm{~mL}$ of aqueous WSPE (at $200 \mathrm{mg} / \mathrm{mL}$ ) from 28 -d-stored probiotic yogurt with PPP was mixed with $7.5 \mathrm{~mL}$ of simulated gastric fluid electrolyte stock solution $[6.9 \mathrm{~mL}$ of $\mathrm{KCl}(0.5 M), 0.9$ $\mathrm{mL}$ of $\mathrm{KH}_{2} \mathrm{PO}_{4}(0.5 M), 12.5 \mathrm{~mL}$ of $\mathrm{NaHCO}_{3}(1 M)$, $11.8 \mathrm{~mL}$ of $\mathrm{NaCl}(2 \mathrm{M}), 0.4 \mathrm{~mL}$ of $\mathrm{MgCl}_{2} \cdot 6 \mathrm{H}_{2} \mathrm{O}(0.15$ $M), 0.5 \mathrm{~mL}\left(\mathrm{NH}_{4}\right)_{2} \mathrm{CO}_{3}(0.5 \mathrm{M})$; volume made up to $400 \mathrm{~mL}$ with Milli-Q water; $\mathrm{pH} 3.0], 1.6 \mathrm{~mL}$ of pepsin stock solution $(25,000 \mathrm{U} / \mathrm{mL}$ in simulated gastric fluid electrolyte stock solution), and $5 \mu \mathrm{L}$ of $\mathrm{CaCl}_{2}(0.3 M)$. The $\mathrm{pH}$ of the mixture was adjusted to 3.0, the volume made up to $20 \mathrm{~mL}$ with Milli-Q water, and digested for $2 \mathrm{~h}$ in a shaking waterbath (model SWB20; Ratek Instruments Pty Ltd., Boronia, VIC, Australia) at $37^{\circ} \mathrm{C}$ with shaking (100 horizontal strokes/min). Subsequently, $20 \mathrm{~mL}$ of gastric chyme was mixed with $11 \mathrm{~mL}$ of simulated intestinal fluid electrolyte stock solution [6.8 $\mathrm{mL}$ of $\mathrm{KCl}(0.5 M), 0.8 \mathrm{~mL}$ of $\mathrm{KH}_{2} \mathrm{PO}_{4}(0.5 M)$, $42.5 \mathrm{~mL}$ of $\mathrm{NaHCO}_{3}(1 M), 9.6 \mathrm{~mL}$ of $\mathrm{NaCl}(2 M), 1.1$ $\mathrm{mL}$ of $\mathrm{MgCl}_{2} \cdot 6 \mathrm{H}_{2} \mathrm{O}(0.15 \mathrm{M})$; volume made up to 400 $\mathrm{mL}$ with Milli-Q water; $\mathrm{pH}$ 7.0], $5.0 \mathrm{~mL}$ of a pancreatin stock solution $(800 \mathrm{U} / \mathrm{mL}$ in simulated intestinal fluid electrolyte stock solution), $2.5 \mathrm{~mL}$ of bile $(160 \mathrm{mM})$, and $40 \mu \mathrm{L}$ of $\mathrm{CaCl}_{2}(0.3 M)$. The $\mathrm{pH}$ of mixture was adjusted to 7.0, and the volume made up to $40 \mathrm{~mL}$ with Milli-Q water, and digested for $2 \mathrm{~h}$ in the water bath at $37^{\circ} \mathrm{C}$ with shaking (100 horizontal strokes $/ \mathrm{min}$ ). The digestate was immediately heated at $95^{\circ} \mathrm{C}$ for $15 \mathrm{~min}$ to inactivate the enzymes, and then cooled to room temperature, frozen, and freeze-dried.

\section{Statistical Analyses}

Experiments were conducted as a randomized splitplot blocked design in time with type of yogurt as the main plot and prebiotic addition and time as subplots; the results obtained were analyzed using the general linear model (GLM) procedure. The design was replicated in triplicate with simultaneous subsampling of the samples, resulting in at least 6 observations $(n \geq 6)$. A paired samples $t$-test was also carried out to explore the effects of gastrointestinal digestion on stability of bioactive peptides using the PROC TTEST procedure. These analyses were performed using SAS software at a significance level of $P<0.05$ (SAS Institute, 1996). In addition, hierarchical cluster analysis was performed to categorize yogurt samples with different culture and prebiotic combinations based on their similarities by applying the squared Euclidean distance and Ward linkage methods to the standardized data set (z-scores) 
of d-28 results using SPSS 22.0 (SPSS Inc., Chicago, IL), with results graphically displayed as a dendrogram.

\section{RESULTS AND DISCUSSION}

Lactic acid bacteria produce proteolytic enzymes during yogurt manufacturing, which cleave peptide bonds of milk proteins, leading to generation of peptides and free AA (Donkor et al., 2007c). In our previous study (Sah et al., 2015b), the viability of probiotic (L. acidophilus, L. casei, and L. paracasei spp. paracasei) and starter (S. thermophilus and L. bulgaricus) cultures in yogurt was improved during $28 \mathrm{~d}$ of refrigerated storage due to supplementation with PPP or inulin, and subsequently the extent of protein hydrolysis increased in yogurts during storage. This resulted in generation of several peptides, which may display antibacterial and anticancer activities.

\section{Antibacterial Activity of Yogurts During Refrigerated Storage}

Despite the large numbers of antibiotics available currently, the growing bacterial resistance against many conventional antibiotics in recent decades has directed the investigation of alternative compounds. In addition, the use of natural antimicrobial compounds has received great attention due to consumer demands for minimally processed food. Thus, inhibitory activities of WSPE were evaluated against gram-negative (E. coli) and gram-positive (S. aureus) bacteria, and the findings are presented in Figure 1 and Table 2. All samples displayed antibacterial activity against both E. coli and $S$. aureus. Moreover, the inhibition zones induced by the WSPE increased significantly $(P$ $<0.05$ ) at the end of storage compared with $\mathrm{d} 1$ of storage, indicating increased generation of the peptides. Overall, enhanced antibacterial activity was observed in the probiotic yogurts supplemented with PPP compared with the nonsupplemented probiotic yogurt, and similar activities were observed for inulin-supplemented yogurts. Furthermore, growth inhibition of WSPE against $E$. coli was comparable to that of ampicillin at $500 \mu \mathrm{g} / \mathrm{mL}(19.94 \pm 1.27 \mathrm{~mm})$. However, the extent of inhibition against $S$. aureus was significantly less than that of ampicillin at $500 \mu \mathrm{g} / \mathrm{mL}(41.72 \pm 1.61 \mathrm{~mm})$. Several potent antibacterial peptides (ABP) liberated from milk proteins have been reported, such as LeuArg-Leu-Lys-Lys-Tyr-Lys-Val-Pro-Gln-Leu $\quad\left(f_{99-109}\right.$ of $\left.\alpha_{\mathrm{S} 1}-\mathrm{CN}\right)$ from the pepsin hydrolysate of bovine casein (Tang et al., 2015). Additionally, Sedaghati et al. (2014) also reported 3 ABP [Met-Met-Lys $\left(\mathrm{f}_{1-3}\right)$, Phe-Phe-SerAsp-Lys $\left(\mathrm{f}_{17-21}\right)$, Ile-Ala-Lys $\left(\mathrm{f}_{22-24}\right)$ ] from bovine $\kappa-\mathrm{CN}$ digested using plasmin. McCann et al. (2005) isolated many ABP derived from the $\mathrm{f}(164-207)$ region of bovine $\alpha_{S_{2}}$ CN from the digested bovine milk proteins by chymosin. Furthermore, the antibacterial activity and selectivity of a peptide depends on various attributes, including peptide charges, amphipathicity, and the size of hydrophobic or hydrophilic domain (Zelezetsky and Tossi, 2006).

Bacterial morphology was determined after treatment with WSPE using scanning electron microscopy. The observations demonstrated that the peptides possessed membrane-lytic activities against microbial cells (Figure 2). Fibrous material, likely due to leakage of

Table 2. Inhibition zones of plain and probiotic yogurts supplemented with or without pineapple peel powder (PPP) or inulin during $28 \mathrm{~d}$ of storage at $4^{\circ} \mathrm{C}$ against Escherichia coli (ATCC CRM-8739; gram-negative) and Staphylococcus aureus ssp. aureus (ATCC 25923; gram-positive) ${ }^{1}$

Inhibition zone $(\mathrm{mm})$

\begin{tabular}{|c|c|c|c|c|c|c|c|}
\hline \multirow{2}{*}{\multicolumn{2}{|c|}{ Yogurt type ${ }^{2}$}} & \multirow{2}{*}{\multicolumn{3}{|c|}{ E. coli }} & \multicolumn{3}{|c|}{ S. aureus } \\
\hline & & & & & \multicolumn{3}{|c|}{ S. aureus } \\
\hline \multicolumn{2}{|r|}{ Prebiotic } & d 1 & d 14 & d 28 & \multicolumn{2}{|c|}{ 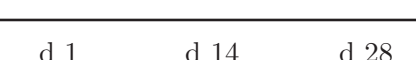 } & d 28 \\
\hline \multirow{5}{*}{$\begin{array}{l}\mathrm{SC} \\
\mathrm{SC}+\mathrm{PC} \\
\mathrm{SC}+\mathrm{PC} \\
\mathrm{SC}+\mathrm{PC} \\
\mathrm{SEM}^{3}\end{array}$} & None & $23.83^{\mathrm{b}, \mathrm{A}}$ & $23.50^{\mathrm{b}, \mathrm{AB}}$ & $23.00^{\mathrm{c}, \mathrm{B}}$ & $10.06^{\mathrm{b}, \mathrm{A}}$ & $9.44^{\mathrm{c}, \mathrm{B}}$ & $10.50^{\mathrm{c}, \mathrm{A}}$ \\
\hline & None & $22.83^{\mathrm{c}, \mathrm{B}}$ & $23.28^{\mathrm{b}, \mathrm{AB}}$ & $23.67^{\mathrm{c}, \mathrm{A}}$ & $10.17^{\mathrm{ab}, \mathrm{B}}$ & $10.28^{\mathrm{b}, \mathrm{B}}$ & $11.00^{\mathrm{bc}, \mathrm{A}}$ \\
\hline & Inulin & $23.17^{\mathrm{bc}, \mathrm{B}}$ & $23.44^{\mathrm{b}, \mathrm{B}}$ & $24.56^{\mathrm{b}, \mathrm{A}}$ & $10.33^{\mathrm{ab}, \mathrm{B}}$ & $10.44^{\mathrm{b}, \mathrm{B}}$ & $11.22^{\mathrm{ab}, \mathrm{A}}$ \\
\hline & PPP & $24.61^{\mathrm{a}, \mathrm{B}}$ & $24.89^{\mathrm{a}, \mathrm{B}}$ & $25.89^{\mathrm{a}, \mathrm{A}}$ & $10.67^{\mathrm{a}, \mathrm{B}}$ & $11.06^{\mathrm{a}, \mathrm{B}}$ & $11.72^{\mathrm{a}, \mathrm{A}}$ \\
\hline & & \multicolumn{3}{|c|}{0.24} & \multicolumn{3}{|c|}{0.19} \\
\hline
\end{tabular}

${ }^{\mathrm{a}-\mathrm{c}}$ Different lowercase superscripts in the same column depict significant differences between means for yogurt types $(P<0.05)$

${ }^{\mathrm{A}, \mathrm{B}}$ Different uppercase superscripts in the same row depict significant differences between means for yogurts with the same culture and prebiotic combination on d 1, 14, and 28 of refrigerated storage $(P<0.05)$.

${ }^{1}$ Results are expressed as mean of 3 trials.

${ }^{2} \mathrm{SC}=$ starter culture (Streptococcus thermophilus + Lactobacillus bulgaricus); $\mathrm{PC}=$ probiotic culture (Lactobacillus acidophilus + Lactobacillus casei + Lactobacillus paracasei).

${ }^{3} \mathrm{SEM}=$ pooled standard error of the mean for predetermined $P<0.05$. 


\section{Day 1}
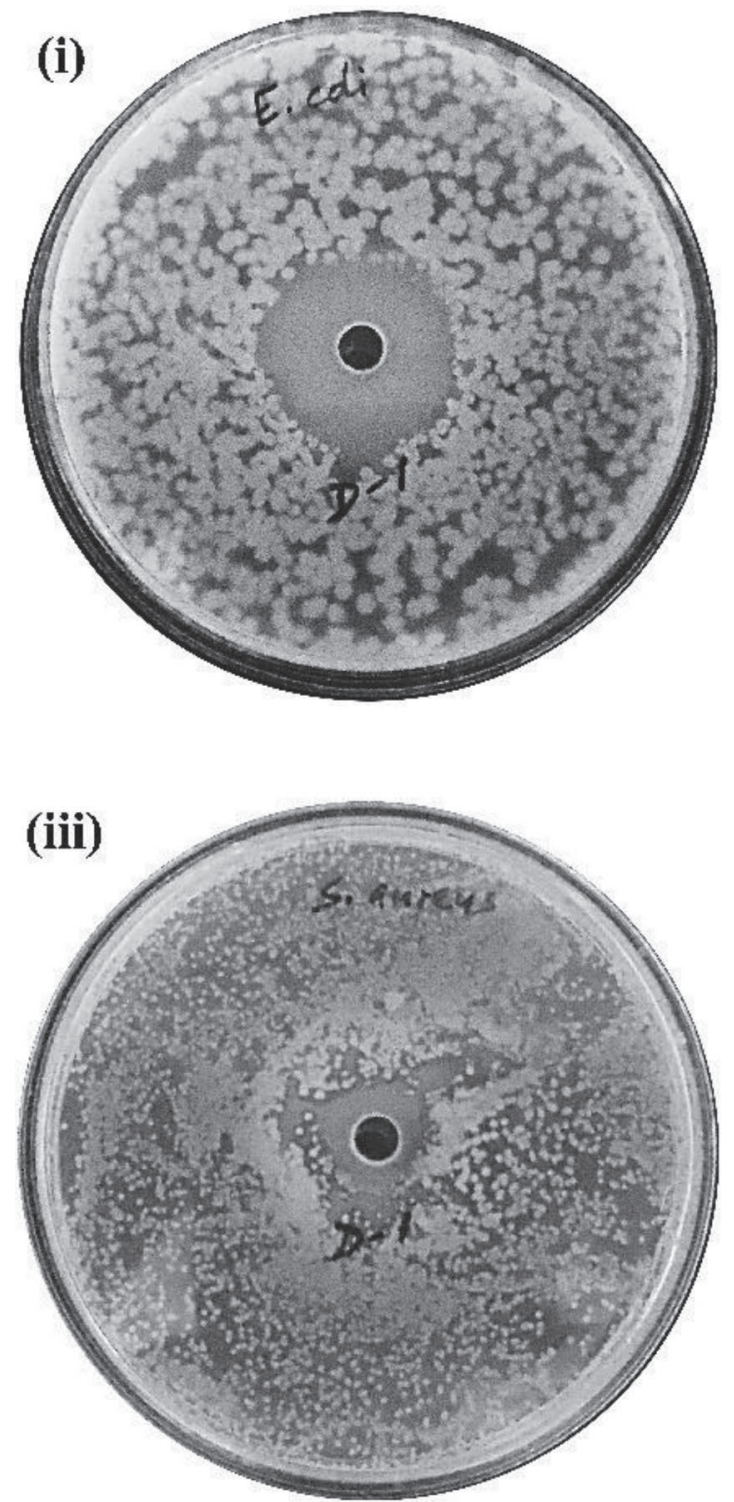

Day 28
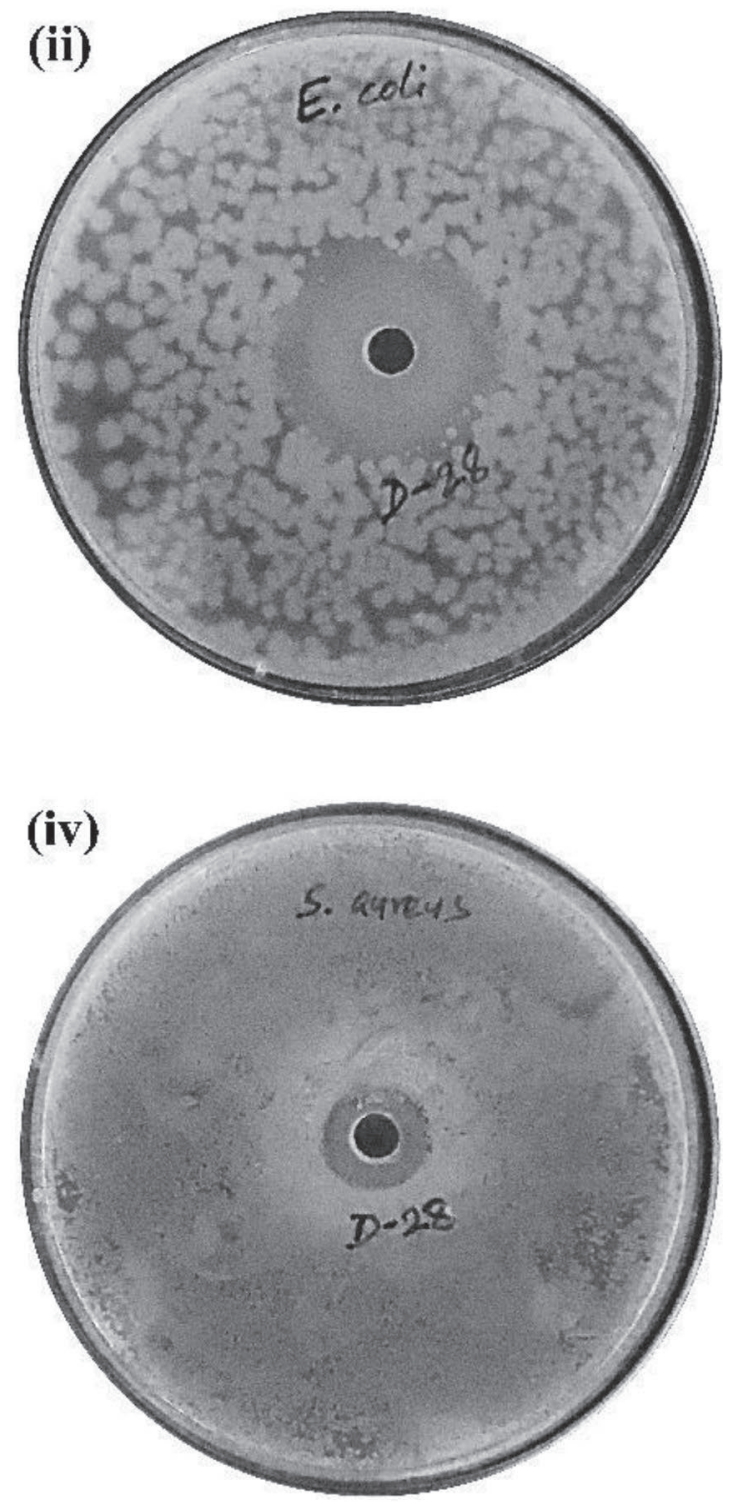

Figure 1. Probiotic yogurts supplemented with pineapple peel powder stored at $4^{\circ} \mathrm{C}$ for $28 \mathrm{~d}$ against test microorganisms: Escherichia coli (i, ii), and Staphylococcus aureus (iii, iv), showing inhibitory zones for d 1 (i and iii) and d 28 (ii and iv).

cell content, and cell debris were seen scattered around the cells (Figures 2B and 2D). Some cationic peptides are believed to interact with gram-negative bacteria first by binding to the anionic lipopolysaccharides of cell membrane (Yeaman and Yount, 2003; Hoskin and Ramamoorthy, 2008). These peptides can also displace divalent cations such as $\mathrm{Ca}^{2+}$ and $\mathrm{Mg}^{2+}$, causing distortion of the outer membrane bilayer because the ions are essential for integrity of the outer membrane (Peterson et al., 1987). Consequently, the membrane lyses, resulting in cell death.

\section{Antiproliferative Activity of Yogurts Against HT-29 Cells During Storage}

Antiproliferative activity of WSPE against cancer cells was investigated by assessing their potency to inhibit the growth of HT-29 colon cancer cells, and the results are presented in Figure 3 and Table 3. All samples reduced proliferation of HT-29 cells to varying degrees, indicating differences in generated WSPE of the yogurts. The antiproliferative activities were stronger in PPP-supplemented probiotic yogurt 
$(56.36 \%)$ compared with the nonsupplemented control probiotic yogurt $(40.52 \%)$ and plain yogurt (35.71\%) after $28 \mathrm{~d}$ of refrigerated storage. Moreover, activities in probiotic yogurt with PPP increased significantly $(P$ $<0.05)$ during storage compared with on d 1 (40.10 vs. $56.36 \%)$. The effectiveness of WSPE was comparable to that of staurosporine at $500 \mathrm{ng} / \mathrm{mL}(36.28 \pm$ $2.80 \%$ ). Several potent anticancer peptides liberated from milk proteins have been reported, such as PhePhe-Ser-Asp-Lys ( $\kappa$-casecidin; $\mathrm{f}_{17-21}$ of bovine $\kappa$-CN) against human leukemic cells lines (Matin and Otani, 2002 ), and Ile-Asn-Lys-Lys-Ile ( $\mathrm{f}_{41-45}$ of $\beta$-CN) against B16F10 melanoma cells (Azevedo et al., 2012). Furthermore, a partially purified peptide subfraction from buffalo cheese acid whey, called $\mathrm{f} 3$, reduced the proliferation of human epithelial colon cancer (Caco-2) cells by modulating the cell cycle (De Simone et al., 2009). The peptide Pro-Gly-Pro-Ile-Pro-Asn $\left(\mathrm{f}_{63-68}\right.$ of $\beta$-CN) inhibited proliferation of SKOV3 human ovarian cancer cells partly by promoting apoptosis by hindering BCL2 pathway (Wang et al., 2013). $\alpha$-Casecidins [Arg-ProLys $\left(f_{1-3}\right)$, Leu-Lys-Lys $\left(f_{101-103}\right)$, and Tyr-Lys $\left(f_{104-105}\right)$ derived from $\left.\alpha_{\mathrm{S} 1}-\mathrm{CN}\right]$ caused necrosis in leukemic $\mathrm{T}$ and B cell lines (Otani and Suzuki, 2003). Bovine lactoferrin reduced the proliferation of $\mathrm{MCF}-7$ breast cancer cells dose-dependently by inducing apoptosis (Zhang et al., 2015). The antiproliferative activity observed in this study requires further investigation to elucidate mechanisms of cell death or suppression.

\section{Synbiotic Effect of Prebiotic and Probiotic on the Overall Antibacterial and Antiproliferative Activities in Yogurts}

Cluster analysis was conducted using hierarchical clustering method with Ward's linkage and revealed 2 clusters based on similarities in measured inhibitory activities against E. coli, S. aureus, and HT29 colon cancer cells during $28 \mathrm{~d}$ of storage at $4^{\circ} \mathrm{C}$ (Figure 4). These findings implied that the liberated peptides behaved differently according to sample types. Overall, nonsupplemented probiotic yogurt (denoted yogurt 2) and probiotic yogurt supplemented with inulin (denoted yogurt 3) displayed similar bioactivities. Plain

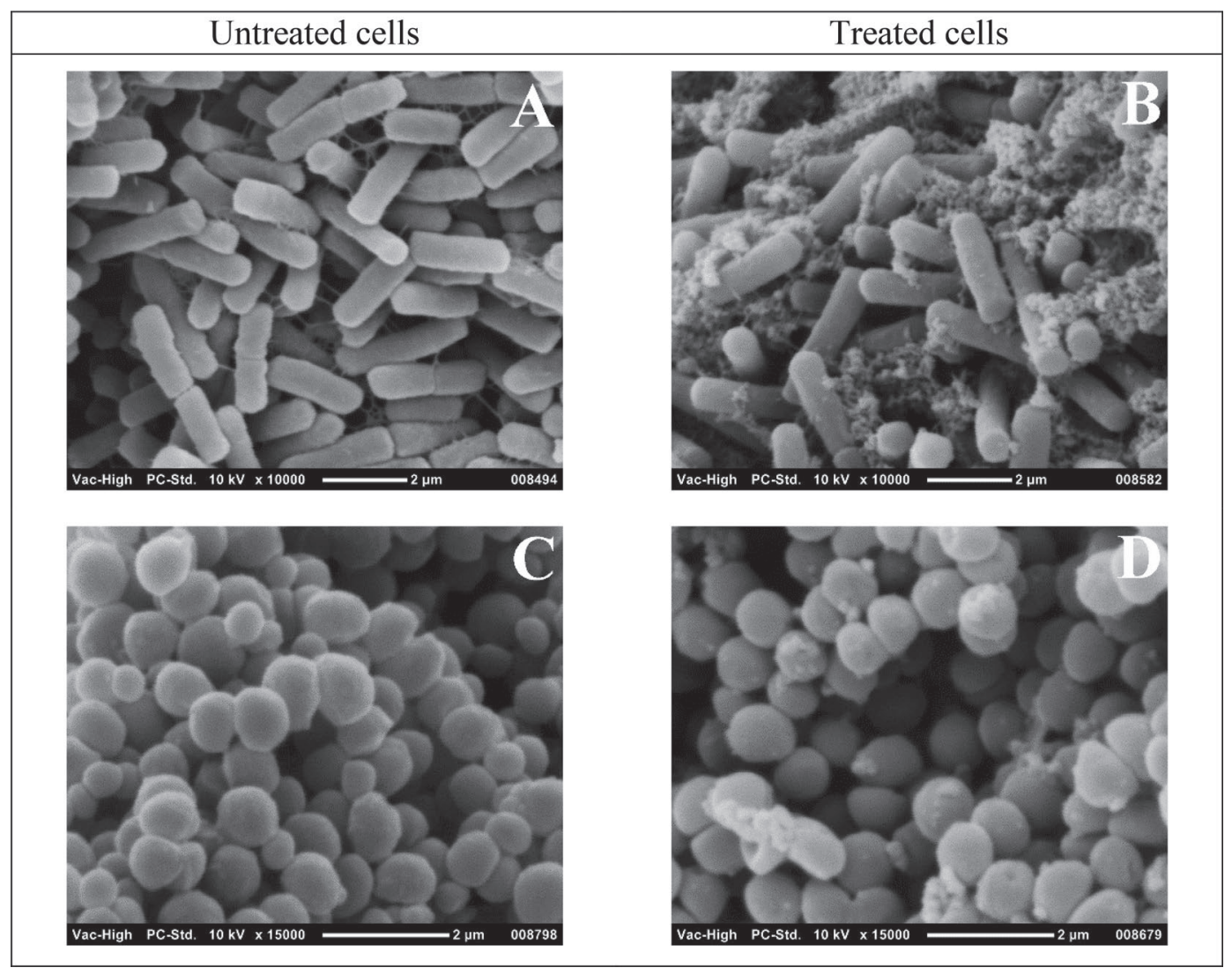

Figure 2. Scanning electron micrographs showing morphological changes of Escherichia coli $(\mathrm{A}=$ untreated control cells; $\mathrm{B}=$ treated cells), and Staphylococcus aureus $\left(\mathrm{C}=\right.$ untreated control cells; $\mathrm{D}=$ treated cells) induced by treating for $6 \mathrm{~h}$ at $37^{\circ} \mathrm{C}$ with water-soluble peptide extract (WSPE) probiotic yogurts supplemented with pineapple peel powder and stored for $28 \mathrm{~d}$. 


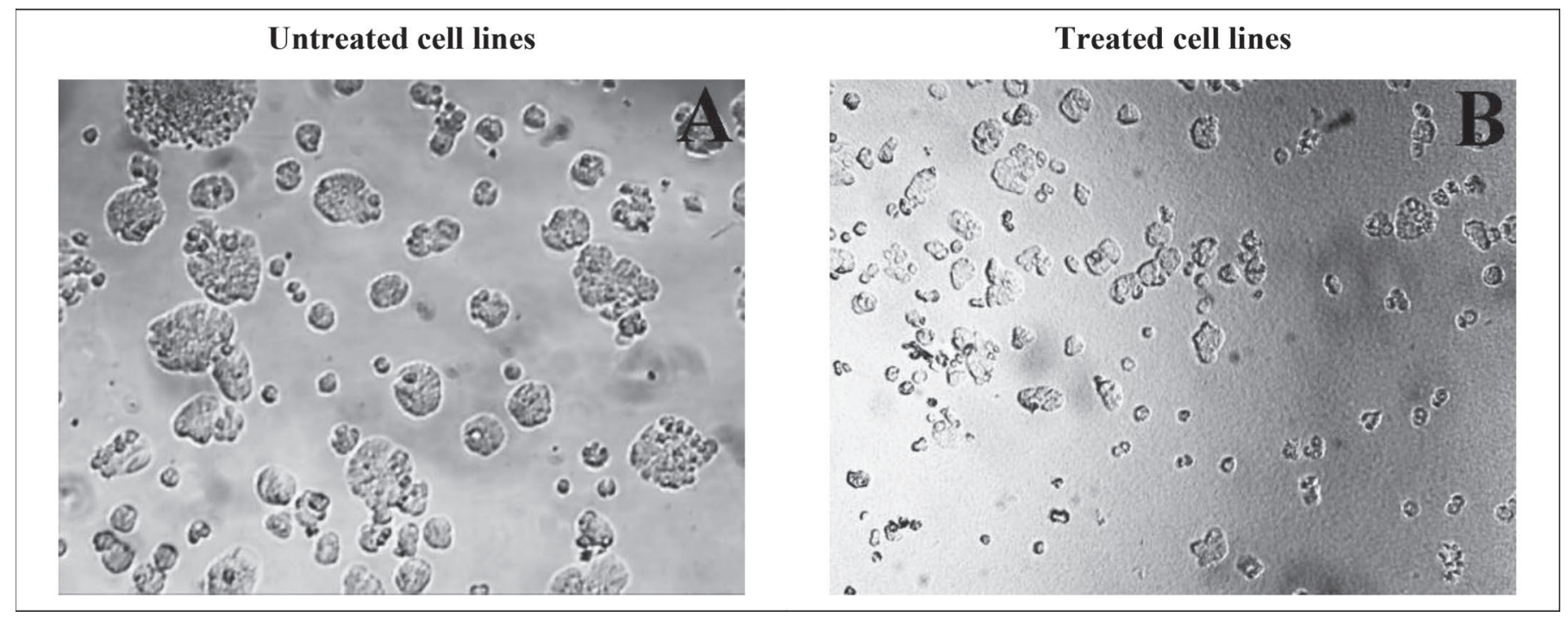

Figure 3. Images examined under phase-contrast microscopy showing morphological changes in HT29 human colon cancer cells: (A) untreated control, and (B) treated for $24 \mathrm{~h}$ at $37^{\circ} \mathrm{C}$ with water-soluble peptide extract (WSPE) probiotic yogurts supplemented with pineapple peel powder and stored for $28 \mathrm{~d}$.

yogurt was arranged in a separate cluster characterized by weak antibacterial and antiproliferative activities, whereas probiotic yogurt with PPP was in a separate cluster showing strong inhibitory activities against bacterial and HT 29 colon cancer cells. Thus, the PPPfortified probiotic yogurt stored for $28 \mathrm{~d}$ was selected to study the stability of measured bioactivities during in vitro GI digestion.

Table 3. Antiproliferative activity of plain and probiotic yogurts supplemented with or without pineapple peel powder (PPP) or inulin during $28 \mathrm{~d}$ of storage at $4^{\circ} \mathrm{C}$ against a human colorectal cancer cell line, HT29 (ATCC HTB38)

\begin{tabular}{|c|c|c|c|c|}
\hline \multicolumn{2}{|c|}{ Yogurt type $^{2}$} & \multicolumn{3}{|c|}{ Antiproliferative activity (\%) } \\
\hline Culture & Prebiotic & d 1 & d 14 & d 28 \\
\hline $\begin{array}{l}\mathrm{SC} \\
\mathrm{SC}+\mathrm{PC} \\
\mathrm{SC}+\mathrm{PC} \\
\mathrm{SC}+\mathrm{PC} \\
\mathrm{SEM}^{3}\end{array}$ & $\begin{array}{l}\text { None } \\
\text { None } \\
\text { Inulin } \\
\text { PPP }\end{array}$ & $\begin{array}{l}44.73^{\mathrm{a}, \mathrm{A}} \\
21.81^{\mathrm{b}, \mathrm{B}} \\
46.78^{\mathrm{a}, \mathrm{A}} \\
40.10^{\mathrm{a}, \mathrm{B}}\end{array}$ & $\begin{array}{c}39.44^{\mathrm{a}, \mathrm{AB}} \\
29.87^{\mathrm{b}, \mathrm{B}} \\
35.66^{\mathrm{ab}, \mathrm{B}} \\
40.94^{\mathrm{a}, \mathrm{B}} \\
2.82\end{array}$ & $\begin{array}{l}35.71^{\mathrm{b}, \mathrm{B}} \\
40.52^{\mathrm{b}, \mathrm{A}} \\
40.36^{\mathrm{b}, \mathrm{AB}} \\
56.36^{\mathrm{a}, \mathrm{A}}\end{array}$ \\
\hline
\end{tabular}

\footnotetext{
${ }^{a, b}$ Different lowercase superscripts in the same column depict significant differences between means for yogurt types $(P<0.05)$.

${ }^{\mathrm{A}, \mathrm{B}}$ Different uppercase superscripts in the same row depict significant differences between means for yogurts with the same culture and prebiotic combination on $\mathrm{d} 1,14$, and 28 of refrigerated storage $(P<$ $0.05)$.

${ }^{1}$ Results are expressed as mean of 3 trials.

${ }^{2} \mathrm{SC}=$ starter culture (Streptococcus thermophilus + Lactobacillus bulgaricus); $\mathrm{PC}=$ probiotic culture (Lactobacillus acidophilus + Lactobacillus casei + Lactobacillus paracasei).

${ }^{3} \mathrm{SEM}=$ pooled standard error of the mean for predetermined $P<$ 0.05 .
}

\section{Stability of Bioactivities During In Vitro GI Digestion}

One of the greatest challenges of in vivo efficacy of bioactive peptides is the ability to reach target organs after oral administration because of hydrolysis

\section{Dendrogram using Ward Linkage Rescaled Distance Cluster Combine}

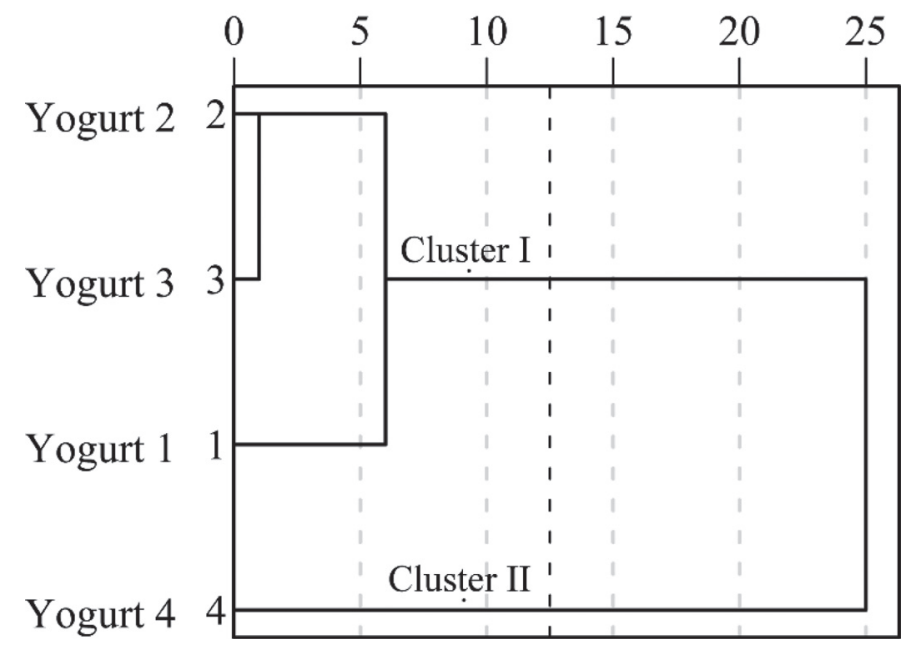

Figure 4. Dendrogram exhibiting the clustering of yogurts according to similarities among measured variables in yogurts stored at $4^{\circ} \mathrm{C}$ in $\mathrm{d} 28$. The measured variables were inhibitory zones against Escherichia coli and Staphylococcus aureus, and antiproliferative activity against HT29 colon cancer cell lines. Yogurt $1=$ fermented using starter culture only; yogurts 2,3 , and $4=$ fermented using both starter and probiotic cultures. Yogurts 3 and 4 were supplemented with inulin and pineapple peel powder, respectively, whereas yogurts 1 and 2 were nonsupplemented control yogurts. 
by digestive enzymes and low $\mathrm{pH}$ in stomach. Results after GI tract simulation with WSPE sample showed insignificant changes $(P>0.05)$ in inhibitory activities against $S$. aureus $(10.94 \pm 0.49 \mathrm{~mm})$ compared with undigested sample $(11.72 \pm 0.49 \mathrm{~mm})$. However, GI tract simulation resulted in significantly lower $(P<$ $0.05)$ inhibitory activities against $E$. coli and HT29 colon cancer cells $(17.28 \pm 0.77 \mathrm{~mm}$ and $27.56 \pm 3.74 \%$, respectively) compared with undigested sample (25.89 $\pm 0.40 \mathrm{~mm}$ and $56.36 \pm 3.73 \%$, respectively). This decrease could have resulted from the breakdown of bioactive peptides of the WSPE due to hydrolysis by the GI tract enzymes. Ao and Li (2013) also reported the degradation of peptide fractions during GI digestion. Consistent with these findings, Su et al. (2007) showed that multi-phosphorylated $\alpha_{S^{-}}$and $\alpha_{S_{2}}-C N$ peptides were not stable during pancreatic digestion. However, peptides containing proline and hydroxyproline residues can usually resist breakdown by digestive enzymes (Segura-Campos et al., 2011). In fact, GI digestion can result in both formation and degradation of bioactive peptides, as reported by Kopf-Bolanz et al. (2014). Therefore, parenteral administration may be the preferable delivery mode for the purified peptides compared with the consumption of bioactive peptides in probiotic yogurts fortified with PPP. Encapsulation of active peptides may be another approach to minimize possible hydrolysis by the GIT system.

\section{CONCLUSIONS}

All WSPE prepared from yogurt samples possessed antibacterial activities against gram-positive and gramnegative bacteria, and activities increased during storage. The WSPE exhibited stronger inhibitory activity against gram-negative compared with gram-positive bacteria. In addition, the WSPE inhibited proliferation of HT29 human colon cancer cells. Generation of inhibitory peptides against bacteria and HT29 human colon cancer cells improved with PPP supplementation of yogurt. However, activities reduced substantially after GI tract digestion. Taken together, the incorporation of PPP and probiotics in yogurts offers new opportunities in the development of novel functional foods, and this approach could lead to the development of novel bioactive peptides having antibacterial and anticancer activity. These findings demand further investigation to isolate and characterize these inhibitory peptides from WSPE.

\section{ACKNOWLEDGMENTS}

The authors are grateful to the Australian Government for offering an Australia Awards Scholarships and
Australia Awards Leadership Program place to B. N. P. Sah.

\section{REFERENCES}

Al-Sheraji, S. H., A. Ismail, M. Y. Manap, S. Mustafa, and R. M. Yusof. 2012. Viability and activity of bifidobacteria during refrigerated storage of yoghurt containing Mangifera pajang fibrous polysaccharides. J. Food Sci. 77:M624-M630. http://dx.doi.org/10.1111/ j.1750-3841.2012.02955.x.

Ao, J., and B. Li. 2013. Stability and antioxidative activities of casein peptide fractions during simulated gastrointestinal digestion in vitro: Charge properties of peptides affect digestive stability. Food Res. Int. 52:334-341. http://dx.doi.org/10.1016/j. foodres.2013.03.036.

Azevedo, R. A., A. K. Ferreira, A. V. V. Auada, K. F. M. Pasqualoto, R. Marques-Porto, D. A. Maria, and I. Lebrun. 2012. Antitumor effect of cationic INKKI peptide from bovine $\beta$-casein on melanoma B16F10. J. Cancer Ther. 3:237-244. http://dx.doi. org/10.4236/jct.2012.34034.

Bhat, Z. F., and H. Bhat. 2011. Milk and dairy products as functional foods: A review. Int. J. Dairy Sci. 6:1-12. http://dx.doi. org/10.3923/ijds.2011.1.12.

Bradford, M. M. 1976. A rapid and sensitive method for the quantitation of microgram quantities of protein utilizing the principle of protein dye binding. Anal. Biochem. 72:248-254.

Choi, J., L. Sabikhi, A. Hassan, and S. Anand. 2012. Bioactive peptides in dairy products. Int. J. Dairy Technol. 65:1-12. http:// dx.doi.org/10.1111/j.1471-0307.2011.00725.x.

De Simone, C., G. Picariello, G. Mamone, P. Stiuso, A. Dicitore, D. Vanacore, L. Chianese, F. Addeo, and P. Ferranti. 2009. Characterisation and cytomodulatory properties of peptides from Mozzarella di Bufala Campana cheese whey. J. Pept. Sci. 15:251-258. http://dx.doi.org/10.1002/psc.1093.

Donkor, O. N., A. Henriksson, T. K. Singh, T. Vasiljevic, and N. P. Shah. 2007b. ACE-inhibitory activity of probiotic yoghurt. Int. Dairy J. 17:1321-1331. http://dx.doi.org/10.1016/j.idairyj.2007.02.009.

Donkor, O. N., A. Henriksson, T. Vasiljevic, and N. P. Shah. 2007c. Proteolytic activity of dairy lactic acid bacteria and probiotics as determinant of growth and in vitro angiotensin-converting enzyme inhibitory activity in fermented milk. Lait 87:21-38. http://dx.doi. org/10.1051/lait:2006023.

Donkor, O. N., S. L. I. Nilmini, P. Stolic, T. Vasiljevic, and N. P. Shah. 2007a. Survival and activity of selected probiotic organisms in settype yoghurt during cold storage. Int. Dairy J. 17:657-665. http:// dx.doi.org/10.1016/j.idairyj.2006.08.006.

Gibson, G. R., H. M. Probert, J. Van Loo, R. A. Rastall, and M. B. Roberfroid. 2004. Dietary modulation of the human colonic microbiota: Updating the concept of prebiotics. Nutr. Res. Rev. 17:259-275. http://dx.doi.org/10.1079/NRR200479.

Giuliani, A., G. Pirri, and S. F. Nicoletto. 2007. Antimicrobial peptides: An overview of a promising class of therapeutics. Cent. Eur. J. Biol. 2:1-33. http://dx.doi.org/10.2478/s11535-007-0010-5.

Goss, P. E., B. L. Lee, T. Badovinac-Crnjevic, K. Strasser-Weippl, Y. Chavarri-Guerra, J. S. Louis, C. Villarreal-Garza, K. UngerSaldaña, M. Ferreyra, M. Debiasi, P. E. R. Liedke, D. Touya, G. Werutsky, M. Higgins, L. Fan, C. Vasconcelos, E. Cazap, C. Vallejos, A. Mohar, F. Knaul, H. Arreola, R. Batura, S. Luciani, R. Sullivan, D. Finkelstein, S. Simon, C. Barrios, R. Kightlinger, A. Gelrud, V. Bychkovsky, G. Lopes, S. Stefani, M. Blaya, F. H. Souza, F. S. Santos, A. Kaemmerer, E. de Azambuja, A. F. C. Zorilla, R. Murillo, J. Jeronimo, V. Tsu, A. Carvalho, C. F. Gil, C. Sternberg, A. Dueñas-Gonzalez, D. Sgroi, M. Cuello, R. Fresco, R. M. Reis, G. Masera, R. Gabús, R. Ribeiro, R. Knust, G. Ismael, E. Rosenblatt, B. Roth, L. Villa, A. L. Solares, M. X. Leon, I. Torres-Vigil, A. Covarrubias-Gomez, A. Hernández, M. Bertolino, G. Schwartsmann, S. Santillana, F. Esteva, L. Fein, M. Mano, H. Gomez, M. Hurlbert, A. Durstine, and G. Azenha. 2013. Planning cancer control in Latin America and the Caribbean. Lancet Oncol. 14:391-436. http://dx.doi.org/10.1016/S1470-2045(13)70048-2. 
Hoskin, D. W., and A. Ramamoorthy. 2008. Studies on anticancer activities of antimicrobial peptides. Biochim. Biophys. Acta Biomembr. 1778:357-375. http://dx.doi.org/10.1016/j.bbamem.2007.11.008.

Kopf-Bolanz, K. A., F. Schwander, M. Gijs, G. Vergères, R. Portmann, and L. Egger. 2014. Impact of milk processing on the generation of peptides during digestion. Int. Dairy J. 35:130-138. http://dx.doi. org/10.1016/j.idairyj.2013.10.012.

Matin, A., and H. Otani. 2002. Cytotoxic and antibacterial activities of chemically synthesized kappa-casecidin and its partial peptide fragments. J. Dairy Res. 69:329-334. http://dx.doi.org/10.1017/ s0022029902005435.

McCann, K. B., B. J. Shiell, W. P. Michalski, A. Lee, J. Wan, H. Roginski, and M. J. Coventry. 2005. Isolation and characterisation of antibacterial peptides derived from the $\mathrm{f}(164-207)$ region of bovine $\alpha_{\mathrm{s} 2}$-casein. Int. Dairy J. 15:133-143. http://dx.doi. org/10.1016/j.idairyj.2004.06.008.

Minekus, M., M. Alminger, P. Alvito, S. Ballance, T. Bohn, C. Bourlieu, F. Carrière, R. Boutrou, M. Corredig, D. Dupont, C. Dufour, L. Egger, M. Golding, S. Karakaya, B. Kirkhus, S. Le Feunteun, U. Lesmes, A. MacIerzanka, A. MacKie, S. Marze, D. J. McClements, O. Ménard, I. Recio, C. N. Santos, R. P. Singh, G. E. Vegarud, M. S. J. Wickham, W. Weitschies, and A. Brodkorb. 2014. A standardised static in vitro digestion method suitable for food-An international consensus. Food Funct. 5:1113-1124. http://dx.doi. org $/ 10.1039 / \mathrm{c} 3$ fo60702j.

Otani, H., and H. Suzuki. 2003. Isolation and characterization of cytotoxic small peptides, $\alpha$-casecidins, from bovine $\alpha_{\mathrm{s} 1}$-casein digested with bovine trypsin. Anim. Sci. J. 74:427-435. http://dx.doi. org/10.1046/j.1344-3941.2003.00135.x.

Peterson, A. A., S. W. Fesik, and E. J. McGroarty. 1987. Decreased binding of antibiotics to lipopolysaccharide from polymyxinresistant strains of Escherichia coli and Salmonella typhimurium. Antimicrob. Agents Chemother. 31:230-237. http://dx.doi. org/10.1128/AAC.31.2.230.

Roberfroid, M. B. 2007. Inulin-type fructans: Functional food ingredients. J. Nutr. 137:2493S-2502S.

Sah, B. N. P., T. Vasiljevic, S. McKechnie, and O. N. Donkor. 2014. Effect of probiotics on antioxidant and antimutagenic activities of crude peptide extract from yogurt. Food Chem. 156:264-270. http://dx.doi.org/10.1016/j.foodchem.2014.01.105.

Sah, B. N. P., T. Vasiljevic, S. McKechnie, and O. N. Donkor. 2015a. Identification of anticancer peptides from bovine milk proteins and their potential roles in management of cancer: A critical review. Compr. Rev. Food Sci. Food Safety 14:123-138. http://dx.doi. org $/ 10.1111 / 1541-4337.12126$

Sah, B. N. P., T. Vasiljevic, S. McKechnie, and O. N. Donkor. 2015b. Effect of refrigerated storage on probiotic viability and the production and stability of antimutagenic and antioxidant peptides in yogurt supplemented with pineapple peel. J. Dairy Sci. 98:59055916. http://dx.doi.org/10.3168/jds.2015-9450.

Sah, B. N. P., T. Vasiljevic, S. McKechnie, and O. N. Donkor. 2015c. Effect of pineapple waste powder on probiotic growth, antioxidant and antimutagenic activities of yogurt. J. Food Sci. Technol. http://dx.doi.org/10.1007/s13197-015-2100-0.

Sah, B. N. P., T. Vasiljevic, S. McKechnie, and O. N. Donkor. 2016. Physicochemical, textural and rheological properties of probiotic yogurt fortified with fibre-rich pineapple peel powder during re- frigerated storage. Food Sci. Technol. (Campinas.) 65:978-986. http://dx.doi.org/10.1016/j.lwt.2015.09.027.

SAS Institute. 1996. SAS/STAT Software: Changes and Enhancements through Release 6.11. SAS Institute Inc., Cary, NC.

Sedaghati, M., H. Ezzatpanah, M. M. A. Boojar, M. T. Ebrahimi, and M. Aminafshar. 2014. Plasmin digest of k-casein as a source of antibacterial peptides. J. Dairy Res. 81:245-251. http://dx.doi. org/10.1017/S0022029914000120.

Segura-Campos, M., L. Chel-Guerrero, D. Betancur-Ancona, and V. M. Hernandez-Escalante. 2011. Bioavailability of bioactive peptides. Food Rev. Int. 27:213-226. http://dx.doi.org/10.1080/8755 9129.2011.563395.

Siegel, R., D. Naishadham, and A. Jemal. 2012. Cancer statistics, 2012. CA Cancer J. Clin. 62:10-29. http://dx.doi.org/10.3322/ caac. 20138.

Su, R., W. Qi, Z. He, S. Yuan, and Y. Zhang. 2007. Pancreatic hydrolysis of bovine casein: Identification and release kinetics of phosphopeptides. Food Chem. 104:276-286. http://dx.doi.org/10.1016/j. foodchem.2006.11.039.

Tang, W. H. Yuan, H. Zhang, L. Wang, H. Qian, and X. Qi. 2015. An antimicrobial peptide screened from casein hydrolyzate by Saccharomyces cerevisiae cell membrane affinity method. Food Contr. 50: http://dx.doi.org/10.1016/j.foodcont.2014.09.030.

Thammarutwasik, P., T. Hongpattarakere, S. Chantachum, K. Kijroongrojana, A. Itharat, W. Reanmongkol, S. Tewtrakul, and B. Ooraikul. 2009. Prebiotics-A review. Songklanakarin J. Sci. Technol. 31:401-408.

Vieira, M., C. Pinheiro, R. Fernandes, J. P. Noronha, and C. Prudêncio. 2014. Antimicrobial activity of quinoxaline 1,4-dioxide with 2 and 3-substituted derivatives. Microbiol. Res. 169:287-293. http:// dx.doi.org/10.1016/j.micres.2013.06.015.

Wang, W., F. Gu, C. Wei, Y. Tang, X. Zheng, M. Ren, and Y. Qin 2013. PGPIPN, a therapeutic hexapeptide, suppressed human ovarian cancer growth by targeting BCL2. PLoS ONE 8: http:// dx.doi.org/10.1371/journal.pone.0060701.

Yan, Z., Z. Zhu, J. Wang, J. Sun, Y. Chen, G. Yang, W. Chen, and Y. Deng. 2013. Synthesis, characterization, and evaluation of a novel inhibitor of $\mathrm{WNT} / \beta$-catenin signaling pathway. Mol. Cancer 12 : http://dx.doi.org/10.1186/1476-4598-12-116.

Yeaman, M. R., and N. Y. Yount. 2003. Mechanisms of antimicrobia peptide action and resistance. Pharmacol. Rev. 55:27-55. http:// dx.doi.org/10.1124/pr.55.1.2.

Yeung, A. T. Y., S. L. Gellatly, and R. E. W. Hancock. 2011. Multifunctional cationic host defence peptides and their clinical applications. Cell. Mol. Life Sci. 68:2161-2176. http://dx.doi.org/10.1007/ s00018-011-0710-x

Zelezetsky, I., and A. Tossi. 2006. Alpha-helical antimicrobial peptides: Using a sequence template to guide structure-activity relationship studies. Biochim. Biophys. Acta Biomembr. 1758:1436-1449. http://dx.doi.org/10.1016/j.bbamem.2006.03.021.

Zhang, Y., C. F. Lima, and L. R. Rodrigues. 2015. In vitro evaluation of bovine lactoferrin potential as an anticancer agent. Int. Dairy J. 40:6-15. http://dx.doi.org/10.1016/j.idairyj.2014.08.016.

Zhao, L., H. Zhang, T. Hao, and S. Li. 2015. In vitro antibacterial activities and mechanism of sugar fatty acid esters against five food-related bacteria. Food Chem. 187:370-377. http://dx.doi. org/10.1016/j.foodchem.2015.04.108. 